\title{
In Vitro Activity of Naturally Occurring Peptides (Defensins) against Listeria monocytogenes ${ }^{1}$
}

\author{
Ação In Vitro de Peptídeos Naturais (Defensinas) Sobre Listeria \\ monocytogenes
}

\author{
Maria da Graça F. Nascimento ${ }^{2}$ \\ James S. Cullor ${ }^{3}$ \\ Michael E. Selsted ${ }^{4}$
}

\begin{abstract}
NASCIMENTO, M. G. F; CULLOR, F. S. ESSELSTED, M. E. In Vitro Activity of Naturally Occurring Peptides (Defensins) against Listeria monocytogenes. Cad. Saúde Públ., Rio de Faneiro, 10 (4): 440-445, Oct/Dec, 1994.

Autoclaved distilled water samples were inoculated with $\underline{L}$. monocytogenes strain $V 7$ and strain $V P H-1$, and incubated aerobically, at 30 C for 48 hours. Each strain was tested individually, and growth curves were determined at 1, 2, 3, 4, 5, 21, 24, and 48 hours. The growth or survival of $L$. monocytogenes was similar for both strains, with survivors at 24 hour-incubation. The microbicidal activity of one synthetic cationic peptide (NP-2) was examined against $\underline{L}$. monocytogenes strain V7, in a water system. Antibacterial activity of $N P-2(1,5$, and $10 \mathrm{~g} / \mathrm{ml})$ was best expressed at 60 minute-incubation, with $10 \mathrm{~g} / \mathrm{ml}$ of peptide, at $30 \mathrm{C}$.
\end{abstract}

Key words: Listeria monocytogenes; Defensins; Control; Lytic Peptide

\section{INTRODUCTION}

Defensins are naturally occurring peptides that exhibit in vitro broad spectrum microbicidal activity to many gram-positive and gram-negative bacteria, yeast and fungi (Cullor et al., 1990; Levitz et al., 1986; Nascimento et al., 1990; Selsted al., 1984; Selsted et al., 1985c). Additionally, defensins also inactivate certain enveloped viruses, without causing any toxic effect or damage to

\footnotetext{
${ }^{1}$ This study was realized at the University of California, Davis, California, U.S.A., and submitted by the author as part of a original dissertation, in partial satisfaction of the requirements for the degree of Doctor of Philosophy in Comparative Pathology.

2 Projeto Saúde Animal, Convênio EMBRAPA/

UFRRF. Km 47 Rodovia Rio-São Paulo, Seropédica, Itaguaí, RF, 23851-970, Brasil.

3 Department of Pathology, Microbiology E Immunology, School of Veterinary Medicine, University of California, Davis, California, 95 616, U.S.A.

${ }^{4}$ Department of Pathology, Microbiology $\mathcal{E}$ Molecular Genetics, School of Medicine, University of California, Irvine, CA, 92 717, U.S.A.
}

the tissue cultures under study (Lehrer et al., 1985). They have been isolated, purified and characterized from the cytoplasmic granules of mammalian phagocytes. These peptides have been isolated from humans (Ganz et al., 1985; Selsted et al., 1985a), rabbit (Lehrer et al., 1983; Selsted et al., 1985b), guinea pig (Selsted \& Harwig, 1987), and rat (Eisenhauer et al., 1989). They are all cationic, basic proteins with molecular weights of 3000-4000 dalton, and range in length from 26 to 39 amino acids. Although their individual spectra of activity are quite broad, there is variation among microbial species and their susceptibility to a particular peptide.

Published reports on the ability of defensins to kill food-borne pathogens are lacking. Information on the microbicidal activity of synthetic defensins as well as knowledge of its activity in a water system are also lacking.

L. monocytogenes, which can be commonly found in the environment (Brackett, 1988) has become a major concern to the food industry because of the outbreaks 
of human listerioses, in the past few years, involving various kinds of foods (Brackett, 1988). The introduction of L. monocytogenes in a food chain can occur by failure of the standard sanitation procedures.

In addition to the wide distribution of $L$. monocytogenes in the environment and food sources, such as ground beef, poultry and turkey meat, pork sausage, raw meat products, ready-to-eat meat products, and milk (Brackett, 1988; Charlton et al., 1990; Genigeorgis et al., 1989, 1990; Johnson et al., 1990), this bacterium can be also isolated from animals (Ralovich, 1984), and has the capacity to cause illness and death in humans (Ralovich, 1984).

Previous studies have confirmed the presence of $L$. monocytogenes in water of rivers and lakes (Dijkstra, 1982; Watkins \& Sleath, 1981), and additional information confirmed that growth initiation is dependent of inoculum size (Genigeorgis \& Riemann, 1979). We investigated the ability of growth of L. monocytogenes in a water system, using a small initial numbers of organisms, to support our major study with defensins in the same system.

Preliminary investigations in our laboratory have indicated that natural NP-1 and synthetic NP-2 were effective against $L$. monocytogenes in buffer systems (Nascimento et al., 1990). The aim of this study was to investigate the ability of a synthetic defensin (NP-2) to kill L. monocytogenes in water. This was an in vitro microbiological assay to search for a possibility of using NP-2 as a potential sanitizer to kill Listeria in water.

\section{METHODS}

\section{Peptide}

The NP-2 peptide, obtained from Dr. M. E. Selsted, was synthesized on the analytical Biosystems 430A instrument as previously described (Selsted et al., 1983). The standard for the NP-2 synthesis used sequential coupling efficiency $>99.0 \%$, which was determined by ninhydrin reactivity. After cleavage from the resin and deprotection of R groups, NP-2 was refolded and dialysed. After lyophilization and purification by ionexchange chromatography, the purified peptide was analyzed and sequenced for amino acids. The degree of secondary and tertiary structure was determined by CD and 2-D NMR spectra (Selsted et al., 1983).

\section{Preparation of Listeria Cultures}

The tested strains of $L$. monocytogenes included strain VPH-1 (Veterinary Public Health Importance $n^{0} 1$ ), serovar $4 b$, isolated from a clinical case (obtained originally from Dr. H. Kinde, California Department of Food and Agriculture), and strain V7, serovar la, a milk isolate (obtained originally from Professor Mike Doyle, University of Georgia, U.S.A.).

After obtaining a 18 hour culture of $L$. monocytogenes strain V7, and strain VPH-1, the organisms were grown in Brain Heart Infusion Broth $(\mathrm{BHI})$, at $30^{\circ} \mathrm{C}$ in a water bath incubator, and isolates in log phase growth were harvest for 10 minutes, at 2000 $\mathrm{rpm}$, at $25^{\circ} \mathrm{C}$. Each supernatant was discarded into disinfectant, the pellet was resuspended in sterilized deionized distilled water, and washed twice in water, at 2300 $\mathrm{rpm}$, at room temperature, for 10 minutes. Cells were suspended in water to an initial density of $1 \times 10^{7} \mathrm{CFU} / \mathrm{ml}$, based on optical density. For the growth curves, it was used approximately $1 \times 10^{3} \mathrm{CFU} / \mathrm{ml}$ of $L$. monocytogenes for strains V7 and VPH-1. For the microbicidal assay, it was used approximately $10^{6} \mathrm{CFU} / \mathrm{ml}$ for strain V7.

\section{Listeria Survival in Water}

Approximately $10^{3}$ to $10^{4} \mathrm{CFU} / \mathrm{ml}$ of $L$. monocytogenes strains V7 and VPH-1 were used for the growth curves in water. Basically, 10 ì 1 of the bacteria solution was inoculated into 90 ì of water. From time intervals, $0,1,2,3,4,5,21,24$ and 48 hours, samples were taken, diluted, and plated, in duplicate, in Tryptose Soy Agar (TSA) plates (Difco Laboratories, Detroid, MI). 


\section{Microbicidal Assay}

For this assay, it was added $0.05 \%$ of $\mathrm{SA}^{\mathrm{TM}} 100$ (serum alternative, Koller Bio-

Tech, Fort Scott, Kansas) to avoid clumping of the cells. Basically, the microbicidal assay consisted of 80 ì 1 of sterilized distilled water, 10 il of NP-2, and 10 ì of $L$.

monocytogenes strain $\mathrm{V} 7$ from a $1 \times 10^{6}$

$\mathrm{CFU} / \mathrm{ml}$ solution, in a total volume of 100 ìl.

The mixtures were plated in duplicate at time "0" (undiluted and one ten fold dilution), and incubated at $30^{\circ} \mathrm{C}$. After 30 and 60 minutes, each mixture was plated, in duplicate, in TSA. Controls for the peptide were assayed with 10 il of $0.01 \%$ acetic acid (original diluent of defensins), and plated using the same procedure described above, as well as control for water.

\section{Plating and Reading Procedures}

The Spiral Plater System model D was used for plating, and counting the surviving colonies after incubation of plates for 24 to 72 hours. Aerobic incubation of TSA plates was done at $37^{\circ} \mathrm{C}$. Plating undiluted mixture allows a $2 \times 10^{1} \mathrm{CFU} / \mathrm{ml}$, and $1: 10$ dilution allows a 2 $\mathrm{x} 10^{2} \mathrm{CFU} / \mathrm{ml}$ lower limit of detection. Consequently, when no colony growth was detected on the killing assay, a result of $>4.0$ logs of killing was determined for undiluted, and $>3.0$ logs for a ten fold dilution.

\section{Analysis of the Results}

Data obtained from growth in water as well as surviving organisms from the assay were recorded as $\mathrm{CFU} / \mathrm{ml}$, averaged from the duplicated plates, and converted to $\log _{10}$. For the killing assay, survival was determined by $\log _{10} \mathrm{C}_{\mathrm{T}}-\mathrm{N}_{\mathrm{T}}$, where $\mathrm{C}_{\mathrm{T}}$ is the number of $\mathrm{CFU} / \mathrm{ml}$ obtained at each control, and $\mathrm{N}_{\mathrm{T}}$ is the number of $\mathrm{CFU} / \mathrm{ml}$ obtained with the incubation with NP-2, both, at each time point $(\mathrm{T})$. The killing of strain $\mathrm{V} 7$ was determined graphically by plotting the $\log _{10}$ $\mathrm{C}_{\mathrm{T}}-\mathrm{N}_{\mathrm{T}}$ of surviving cell populations at each specific time point.

\section{RESULTS AND DISCUSSION}

\section{Growth and Survival Patterns of L. monocytogenes in Water}

L. monocytogenes strains V7 and VPH-1 showed their ability to grow or survive in a distilled water system, at $30^{\circ} \mathrm{C}$.

We were able to detect both strains of $L$. monocytogenes for up to 24 hours in water. An average of $1.2 \times 10^{2} \mathrm{CFU} / \mathrm{ml}$ of strain V7 was detected at 24 hours. $A \log _{10}$ decrease of 1.12 in $\mathrm{CFU} / \mathrm{ml}$ was thus determined in water. An average of $2.7 \times 10^{2} \mathrm{CFU} / \mathrm{ml}$ of strain VPH-1 was detected in water, at 24 hours. A $\log _{10}$ decrease of 1.16 in $\mathrm{CFU} / \mathrm{ml}$ was thus determined (Figure 1).

FIGURE 1. Survival of L. monocytogenes Strains VPH-1 and V7 in Deionized Water, Incubated at $30^{\circ} \mathrm{C}$, for up to 48 Hours (Cell count is based on a detection limit of 20 cells/ml water)

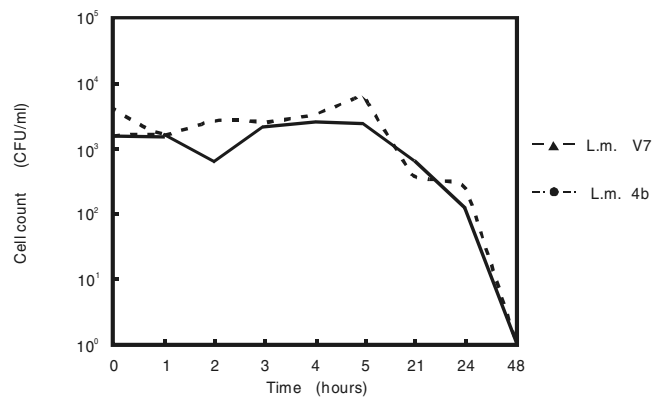


The probability of growth initiation is dependent of inoculum size (Genigeorgis \& Riemann, 1979). As the environment becomes more inhibitory it takes more cells to initiate growth. Despite the small inoculum of $L$. monocytogenes (approximately $10^{3} \mathrm{CFU} / \mathrm{ml}$ ) and the osmotic pressure of deionized water, we found survivors at 24 hour-incubation, at $30^{\circ} \mathrm{C}$.

These results demonstrated the ability of low numbers of Listeria, approximately $10^{3}$ $\mathrm{CFU} / \mathrm{ml}$, to grow, as it was observed after the first two to three hours of incubation, and survive up to 24 hours, in a pure water system (Figure 1). It could be observed that after a short decrease in number of cells, both strains of $L$. monocytogenes showed an apparent growth (Figure 1), which we find difficulties to explain. It is difficult to reveal the sequential changes that occur in individual cells during their interdivision cycle. Since we did not have a synchronized culture of bacteria, a reasonable conclusion to explain some growth might be that the time of transition between the growth phases varies even within each particular phase. One might expect that not all cells would stop growth in the stationary phase at the same time. Even in the same conditions of no nutrients to allow normal cell multiplication, some cells might still hold some intracellular conditions to allow growth in water. Therefore, our study revealed only the general features of the growth of $L$. monocytogenes in water, as expected, since it was not designed to show details about the many parts of the cell functioning in the water system.

\section{Listericidal Effect of Synthetic NP-2 in Water}

Defensins are remarkably abundant in the neutrophils of many mammalian species, and several published reports describe their capacity of killing microorganisms (Cullor et al., 1990; Levitz et al., 1986; Lehrer et al., 1985; Nascimento et al., 1990; Selsted al., 1984; Selsted et al., 1985c).

It was previously reported that outbred New Zealand White rabbit PMN contained two defensins, NP-1 and NP-2, and that these differ from each other only by a single amino acid substitution (Selsted et al., 1985b). Few references were so far founded about the activity of the synthetic NP-2 and the use of a defensin assay against $L$. monocytogenes (Nascimento, et al., 1990). The present data thus expand our previous investigation in which rabbit defensin NP-1 and synthetic NP-2 showed potent listericidal action in buffer, at 60 minutes with either peptide, with no surviving organisms being detected by our plating procedures. Since either natural NP-1 or synthetic NP-2 exhibited substantially the same antimicrobial activity against $L$. monocytogenes, in buffer, we decided to go further in our studies with synthetic NP-2.

For the killing assay, only one strain was tested with NP-2, to avoid duplications. The initial concentration of $L$. monocytogenes strain V7 was $2.2 \times 10^{5} \mathrm{CFU} / \mathrm{ml}$, and the results of this killing assay with NP-2 $(1,5$, and $10 \mathrm{ig} / \mathrm{ml}$ ) in a water system are graphically presented (Figure 2).

FIGURE 2. Bactericidal Activity of Synthetic Defensin NP-2 against L. monocytogenes Strain V7, in a Pure Water System, for 30 and 60 Minute-Incubations, at $30^{\circ} \mathrm{C}$

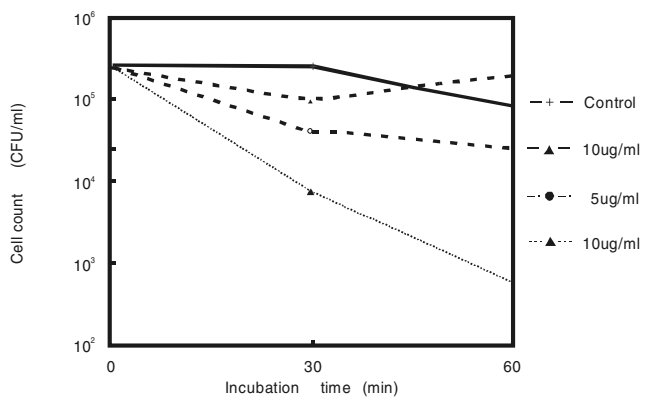


Our data provide important information regarding the antimicrobial activity of a synthetic defensin (NP-2) in water. To our knowledge this is the first report to test the activity of any defensin in water. It is well defined that defensins from natural sources (PMNs) are released from the their cytoplasmic granules in the lumen of the phagocytic vesicles. The intraphagosomal environment in neutrophils has not been completely studied, but we know that their $\mathrm{pH}$ is mildly alkaline at first and gradually acidifies. We could expect that defensins would work in vitro under the same circunstances, but we did not know if the killing activity of defensins would hold in water. Our data showed that at 30 minuteincubation, the controls remained almost the same in numbers, with a slight increase, and dropped 0.42 logs at 60 minute-incubation (Figure 2). A few cells were detected after a 60 minute-incubation of $L$. monocytogenes with $10 \mathrm{ig} / \mathrm{ml}$ of NP-2, showing the efficacy of the killing activity of synthetic defensin, NP-2, in vitro, in a water system, against $L$. monocytogenes strain $\mathrm{V} 7$. This finding is important as we arise the possibility of using NP-2 in the future as a potential sanitizer in water.

Although various other natural cationic peptides have been reported to exert antibacterial and antifungal effects in vitro, limited to buffer systems, our study indicated that synthetic NP-2, has listericidal activity in water. Consequentely, this peptide may contribute, in the future, to reduce or to eliminate $L$. monocytogenes from the food industry, and food products, if added to the rinsing water.

\section{RESUMO}

NASCIMENTO, M. G. F.; CULLOR, J. S. \& SELSTED, M. E. Ação In Vitro de Peptídeos Naturais (Defensinas) Sobre Listeria monocytogenes. Cad. Saúde Públ., Rio de Janeiro, 10 (4): 440-445, out/dez, 1994.

Amostras de água destilada, autoclavadas, foram inoculadas com L. monocytogenes cepa V7 e cepa VPH-1, e incubadas, aerobicamente, a $30^{\circ} \mathrm{C}$ por 48 horas. Cada cepa foi testada individualmente, $\mathrm{e}$ determinou-se curvas de crescimento a 1, 2, 3, $4,5,21,24$, e 48 horas. O crescimento ou sobrevivência das duas cepas foi semelhante e encontrou-se sobreviventes em 24 horas de incubação. Examinou-se a atividade bactericida de um dos peptídeos catiônicos sintéticos (NP-2) contra L. monocytogenes cepa $\mathrm{V} 7$, em sistema aquoso. A atividade antibacteriana de NP-2 $(1,5$, and $10 \mathrm{i} g / \mathrm{ml})$ foi melhor aos 60 minutos de incubação, com 10 ì $/ \mathrm{ml}$ de peptídeo, a $30 \mathrm{C}$.

Palavras-Chave: Listeria monocytogenes; Defensinas; Controle; Peptídeo Microbicida

\section{REFERENCES}

BRACKETT, R. E., 1988. Presence and persistence of Listeria monocytogenes in food and water. Food Technology, 42: 162-164.

CHARLTON, B. R.; KINDE, H. \& JENSEN, L. H., 1990. Environmental survey for Listeria species in California milk processing plants. Fournal of Food Protection, 53: 198-201.

CULLOR, J. S.; MANNIS, M. J.; MURPHY, C. J.; SMITH, W. L.; SELSTED, M. E. \& REID, T. W., 1990. In vitro antimicrobial activity of defensins against ocular pathogens. Archives of Ophthalmology, 108: 861-864.

DIJKSTRA, R. G., 1982. The occurrence of $L$. monocytogenes in surface water of canal and lakes, in ditches of one big polder and in the effluents and canals of a sewage treatment plant. Zentralblatt für Bakteriologie, Hygiene, Abteilung 1, Originale B, 176: 202-205. 
EISENHAUER, P. B.; HARWIG, S. S.; SZKLARED, D.; GANZ, T.; SELSTED, M. E. \& LEHRER, R. I., 1989. Purification and antimicrobial properties of three defensins from rat neutrophis. Infection and Immunity, 57: 2021-2027.

GANZ, T.; SELSTED, M. E.; SZKLAREK, D.; HARWIG, S. S. L.; DAHER, K. \& LEHRER, R. I., 1985. Defensins: natural peptide antibiotics of human neutrophils. Journal of Clinical Investigation, 76: 1427-1435.

GENIGEORGIS, C. A. \& RIEMANN, H., 1979. Food processing and hygiene. In: Food-borne Infections (H. Riemann \& F. L. Bryan, eds.), Chapter XII, $2^{\text {nd }}$ ed., New York: Academic Press.

GENIGEORGIS, C. A.; DUTULESCU, D. \& GARAYZABAL, J. F., 1989. Prevalence of Listeria spp in poultry meat at the supermarket and slaughterhouse level. Journal of Food Protection, 52: 618-624, 630.

GENIGEORGIS, C. A.; OANCA, P. \& DUTULESCU, D., 1990. Prevalence of Listeria spp in turkey meat at the supermarket and slaughterhouse level. Journal of Food Protection, 53: 282-288.

JOHNSON, J. L.; DOYLE, M. P. \& CASSENS, R. G., 1990. Listeria monocytogenes and other Listeria spp in meat and meat products - A review. Journal of Food Protection, 53: 81-91.

LEHRER, R. I.; SELSTED, M. E.; SZKLAREK, D. \& FLEISCHMANN, J., 1983. Antibacterial activity of microbicidal cationic proteins 1 and 2 , natural peptide antibiotics of rabbit lung macrophages. Infection and Immunity, 42: 10-14.

LEHRER, R. I.; DAHER, K.; GANZ, T. \& SELSTED, M. E., 1985. Direct inactivation of virosis by MCP-1 and MCP-2, natural peptide antibiotics from rabbit leukocytes. Journal of Virology, 54: 467-472.

LEVITZ, S. M.; SELSTED, M. E.; GANZ, T.; LEHRER, R. I. \& DIAMOND, R. D., 1986. In vitro killing of spores and hyphae of Aspergillus fumigatusand Rhizopus oryzaeby rabbit neutrophil cationic peptides and bronchoalveolar macrophages. Journal of Infectious Disease, 154: 483-489.
NASCIMENTO, M. G. F.; CULLOR, J. S.; SELSTED, M. E. \& GENIGEORGIS, C. A., 1990. Antimicrobial Effect of Natural and Synthetic Peptides on Pathogenic Listeria monocytogenes. $11^{\text {th }}$ Annual Western Food Animal Disease Research Conference, Reno, Nevada, March 7-8. (Mimeo.)

SELSTED, M. E.; SZLAREK, D. \& LEHRER, R. I., 1984. Purification and antimicrobial activity of antimicrobial peptides of rabbit granulocytes. Infectious Immunity, 45: 150-154.

SELSTED, M. E.; HARWIG, S. S. L.; GANZ, T.; SCHILLING, J. W. \& LEHRER, R. I., 1985a. Primary structures of three human neutrophil defensins. Journal of Clinical Investigation, 76: 1436-1439.

SELSTED, M. E.; BROWN, D. M.; DeLANGE, R. J. \& LEHRER, R. I., 1985b. Primary structures of six antimicrobial peptides of rabbit peritoneal neutrophils. Journal of Biological Chemistry, 260: 4579-4585.

SELSTED, M. E.; SZLAREK, D.; GANZ, T. \& LEHRER, R. I., 1985c. Activity of rabbit leukocyte peptides against Candida albicans. Infectious and Immunity, 49: 202-206.

SELSTED, M. E. \& HARWIG, S. S. L., 1987. Purification, primary structure and antimicrobial activities of a guinea pig neutrophil defensin. Infection and Immunity, 55: 2281-2286.

RALOVICH, B., 1984. Listeriosis Research. Present Situation and Perspective. Budapest: Akadémiai Kiadó.

WATKINS, J. \& SLEATH, K. P., 1981. Isolation and enumeration of $L$. monocytogenesfrom sewage, sewage sludge and river water. Journal of Applied Bacteriology, 50: 01-09. 